\title{
DNA replication in the halophilic archaeobacterium Haloferax volcanii in the absence of protein synthesis
}

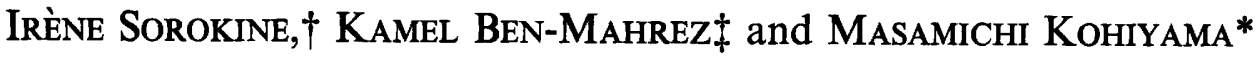 \\ Institut Jacques Monod, CNRS, Université Paris VII, 2 place Jussieu 75251, Paris Cédex 05, France
}

(Received 25 February 1993; revised 4 May 1993; accepted 18 May 1993)

\begin{abstract}
In Haloferax volcanii, DNA replication is not arrested in the absence of protein synthesis. This DNA replication occurs either in complete medium during the inhibition of protein synthesis by anisomycin or in minimal medium during amino acid starvation of an auxotrophic mutant his-1. Once established, this DNA synthesis is permanent. It is also sensitive to aphidicolin, an inhibitor of eukaryotic chromosomal DNA replication. The entire chromosome seems to participate in this replication whereas the synthesis of the resident pHV2 plasmid is reversibly inhibited.
\end{abstract}

\section{Introduction}

Chromosomal DNA replication is a key event in the life of all organisms and, consequently, considerable effort has been expended to understand it. In the best studied member of the eubacteria, Escherichia coli, DNA replication has been shown to be controlled mainly at the level of initiation (for reviews, see McMacken et al., 1987 and von Meyenburg \& Hansen, 1987). In vivo studies have revealed that protein synthesis is required for the reinitiation of new rounds of DNA replication but not for completing on-going ones. Inhibition of protein synthesis results in a complete cessation of DNA synthesis after the termination of on-going rounds of DNA replication (Lark et al., 1963; Maaloe \& Hanawalt, 1961).

In archaeobacteria, members of a third cell lineage (Torreblanca et al., 1986; Woese \& Olsen, 1986), our knowledge of the control of DNA replication is extremely limited and restricted to the characterization of certain DNA polymerases (Ben Mahrez et al., 1991; Elie et al., 1989; Hamal et al., 1990; Klimczak et al., 1985a, b; Kohiyama et al., 1986; Nakayama \& Kohiyama, 1985; Nakayama et al., 1988; Salhi et al., 1990; Zabel et al., 1985). Here, we examine the effect on DNA synthesis of

*Author for correspondence. Tel. +33144276948; fax +33144273580 .

† Present address: CE-FAR, IPSN-DPHD-SARAM, BP 692265 Fontenay-aux-Roses Cédex, France.

¥Present address: Laboratoire de Biochimie, Faculté de Médecine Dentaire, 5000 Monastir, Tunisia.

Abbreviation: DAPI, 4',6-diamidino-2-phenylindole. $2 \mathrm{HCl}$. amino acid starvation and inhibition of protein synthesis by anisomycin in the aerobic chemo-organotroph Haloferax volcanii (Torreblanca et al., 1986).

Members of the genus Haloferax are only moderately halophilic, requiring $2-3 \mathrm{M}-\mathrm{NaCl}$ for optimal growth, and are capable of growth on single carbon sources. We have chosen to study an auxotrophic mutant of Haloferax volcanii, in which we previously reported the continuation of DNA synthesis during amino acid starvation (Sorokine \& Kohiyama, 1988).

In this report, we show that replication of the chromosomal DNA but not of the resident pHV2 plasmid (Charlebois et al., 1987) is independent of protein synthesis. Continuous DNA synthesis occurs either when a required amino acid is removed or when the protein synthesis inhibitor anisomycin is added. The observed DNA synthesis does not need to be induced, and all the chromosomal DNA but not the pHV2 plasmid of $H$. volcanii is apparently replicated. The inhibition of $\mathrm{pHV} 2$ plasmid replication is a reversible event.

\section{Methods}

Chemicals and radioisotopes. Aphidicolin, anisomycin, histidine and 4',6-diamidino-2-phenylindole.2HCl (DAPI) were obtained from Sigma. Kanamycin was from Appligène laboratories. $\left[\alpha-{ }^{32} \mathrm{P}\right] \mathrm{dTTP}$ and $\left[\alpha-{ }^{32} \mathrm{P}\right] \mathrm{dATP}\left[3000 \mathrm{Ci}(110 \mathrm{TBq}) \mathrm{mmol}^{-1}\right],\left[\right.$ methyl $\left.{ }^{3} \mathrm{H}\right]$ thymidine $[44 \mathrm{Ci}$ $\left.(1628 \mathrm{GBq}) \mathrm{mmol}^{-1}\right]$, $\left[\right.$ methyl $\left.{ }^{14} \mathrm{C}\right]$ thymidine $\quad[25 \mathrm{mCi}(925 \mathrm{mBq})$ $\left.\mathrm{mmol}^{-1}\right]$ and $\left[{ }^{3} \mathrm{H}\right] \mathrm{L}$-alanine $\left[59 \mathrm{Ci}(2183 \mathrm{GBq}) \mathrm{mmol}^{-1}\right]$ were obtained from Amersham. XhoI and PstI were from Boehringer Mannheim.

Bacteria. The bacterial strain used is an auxotrophic his-1 mutant of Haloferax volcanii DS2. This mutant, WR201, was provided by Dr Mevarech, University of Tel Aviv, Israel (Mevarech \& Werczberger, 1985). 

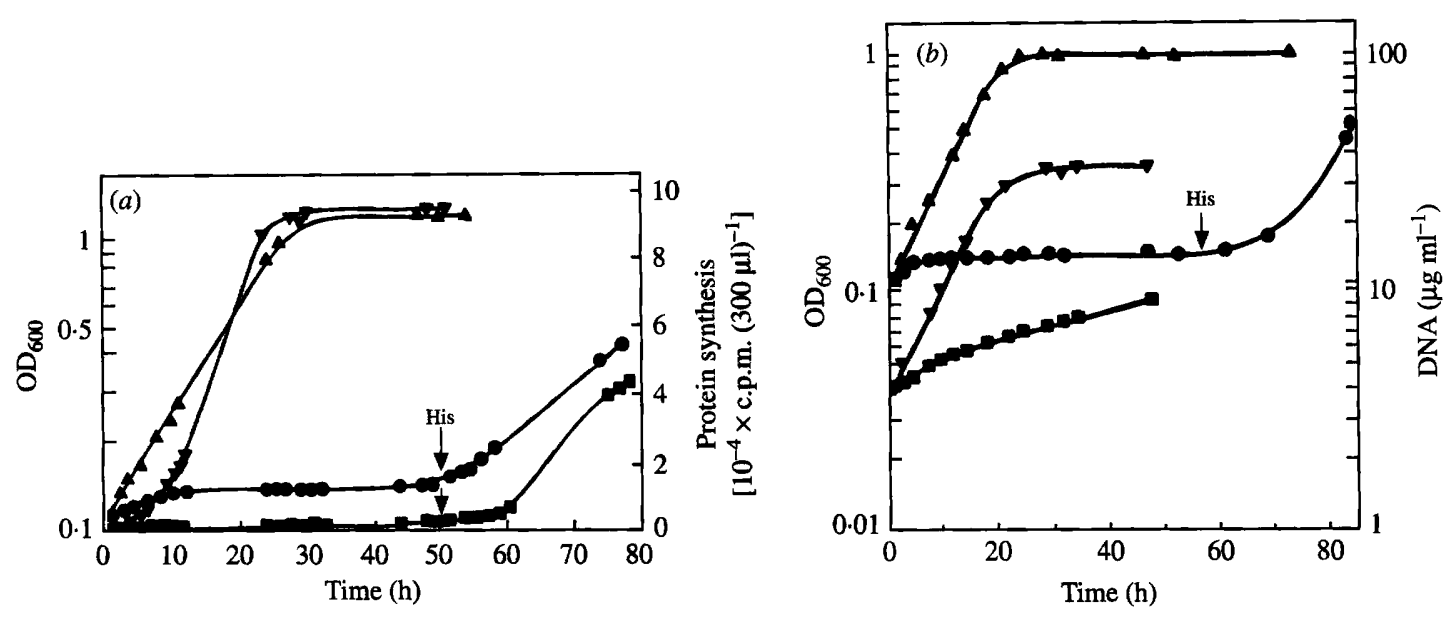

Fig. 1. Effect of histidine deficiency on bacterial growth, DNA replication and protein synthesis in a his-1 mutant of $H$. volcanii. An exponential culture of the his-1 mutant in minimal medium supplemented with histidine $\left(\mathrm{MM}^{+}\right)$was washed in minimal medium without histidine $\left(\mathrm{MM}^{-}\right)$at $\mathrm{OD}_{600}=0.1$ and divided into two portions. Histidine was added to one at $0 \mathrm{~h}$ and this culture served as control. L- $\left.{ }^{3} \mathrm{H}\right]$ Alanine $\left(1.4 \mu \mathrm{Ci} \mathrm{ml}^{-1}\right)$ was then added to both cultures in the presence of $1 \mathrm{mM}-\mathrm{L}$-alanine and incubation was continued for the indicated times at $37^{\circ} \mathrm{C}$. Results are shown for cultures grown in $\mathrm{MM}^{+}(\boldsymbol{\Delta}, \boldsymbol{\nabla})$ and in $\mathrm{MM}^{-}(\boldsymbol{O}, \boldsymbol{\square})$. (a) Culture during exponential growth: $\mathrm{OD}_{600}\left(\log\right.$ scale) in $\mathrm{MM}^{+}(\boldsymbol{\Delta})$ and radioactive labelling (linear scale) of bacteria $(\boldsymbol{\nabla})$. Culture during amino acid starvation: $\mathrm{OD}_{600}$ in $\mathrm{MM}^{-}(\mathbf{O})$ and radioactive labelling of bacteria with $\mathrm{L}-\left[{ }^{3} \mathrm{H}\right]$ alanine $(\boldsymbol{\square})$. (b) Culture during exponential growth: $\mathrm{OD}_{600}$ in $\mathrm{MM}^{+}(\boldsymbol{\Lambda})$ and DNA content measured by fluorometry using the DAPI method $(\boldsymbol{\nabla})$. Culture during amino acid starvation: $\mathrm{OD}_{600}$ in $\mathrm{MM}^{-}(\Theta)$ and DNA content measured by fluorometry using the DAPI method $(\boldsymbol{\square})$. The arrow indicates the time of readdition of histidine to $\mathrm{MM}^{-}$cultures.

Media, growth conditions and amino acid starvation. Bacteria were grown in a salt mixture containing $\left(1^{-1}\right) 206 \mathrm{~g} \mathrm{NaCl}, 36.9 \mathrm{~g}$ $\mathrm{MgSO}_{4} .7 \mathrm{H}_{2} \mathrm{O}, 5 \mathrm{ml} 1 \mathrm{M}-\mathrm{KCl}$, and $1.7 \mathrm{ml}$ of a $75 \mathrm{mg} \mathrm{l}^{-1}$ solution of $\mathrm{MnCl}_{2}$. For complete medium (CM), $5 \mathrm{~g}$ yeast extract (Difco) $\mathrm{l}^{-1}$ was added. When minimal medium (MM) was prepared, the following components were added: $5 \mathrm{ml} 1 \mathrm{M}-\mathrm{NH}_{4} \mathrm{Cl}, 45 \mathrm{ml} 10 \%$ (v/v) glycerol, $5 \mathrm{ml} 10 \%(\mathrm{w} / \mathrm{v})$ succinate, $1 \mathrm{ml}$ trace element solution ( $30 \mathrm{mg} \mathrm{MnCl}$, $44 \mathrm{mg} \mathrm{ZnSO}$, $230 \mathrm{mg} \mathrm{FeSO}_{4}$, and $5 \mathrm{mg} \mathrm{CuSO}_{4}$ per $100 \mathrm{ml}$ ). In each case, after the medium had been autoclaved and cooled, $5 \mathrm{ml} 10 \%$ (w/v) $\mathrm{CaCl}_{2} .2 \mathrm{H}_{2} \mathrm{O}$ and $2 \mathrm{ml} 0.5 \mathrm{M}-\mathrm{K}_{2} \mathrm{HPO}_{4}$ were added; the $\mathrm{pH}$ was then adjusted to 7.2 (Mevarech \& Werczberger, 1985). When needed, histidine (final concn, $50 \mu \mathrm{g} \mathrm{m}^{-1}$ ) was added to minimal medium $\left(\mathrm{MM}^{+}\right)$; the medium without histidine was denoted $\mathrm{MM}^{-}$. For agar plates, $25 \mathrm{~g}$ Bacto-Agar (Difco) $\mathbf{1}^{-1}$ was added. Bacteria were grown at $37^{\circ} \mathrm{C}$ with shaking. Kanamycin was included in $\mathrm{CM}, \mathrm{MM}^{+}$and $\mathrm{MM}^{-}$ at $50 \mu \mathrm{g} \mathrm{ml}^{-1}$ to avoid contamination with halotolerant eubacteria. Growth was followed by measuring $\mathrm{OD}_{600}$.

For kinetic experiments, freshly inoculated cultures were shaken at $37^{\circ} \mathrm{C}$ until the cells had reached an $\mathrm{OD}_{600}$ of $0.1-0.15$ (corresponding to a viable count of $1.2-2.5 \times 10^{8}$ c.f.u. $\mathrm{ml}^{-1}$ ). The cells were then centrifuged $\left(6000 \mathrm{~g}, 12^{\circ} \mathrm{C}, 15 \mathrm{~min}\right)$, washed with two vols $\mathrm{CM}$ (to remove antibiotics) or $\mathrm{MM}^{-}$(to remove histidine), and resuspended in the same volume of CM or MM (supplemented or not with histine). At this point chemicals and radioisotopes were added.

Determination of DNA replication by radioactive labelling of DNA or fluorometric determination using DAPI. For the determination of DNA concentration, the his-1 mutant culture was radioactively labelled with [methyl ${ }^{3} \mathrm{H}$ ] thymidine $\left(0.5 \mu \mathrm{Ci} \mathrm{ml}^{-1}\right)$ in the presence of thymidine $\left(4 \mu \mathrm{g} \mathrm{ml}^{-1}\right)$ in $\mathrm{MM}$, or $\left[\right.$ methyl $\left.^{3} \mathrm{H}\right]$ thymidine alone $\left(1 \mu \mathrm{Ci} \mathrm{ml}^{-1}\right)$ in $\mathrm{CM}$. Samples were removed at different times, the DNA was precipitated by addition of ice-cold $5 \%(\mathrm{w} / \mathrm{v})$ trichloroacetic acid (TCA) containing $0.02 \mathrm{M}$-sodium pyrophosphate and collected on Whatman GFB filters. The filters were dried and the radioactivity was determined in a scintillation counter. Fluorometric determination of total DNA per cell was performed according to the technique described by Legros \& Kepes (1985) and modified as follows: samples of bacteria $(300 \mu l)$ were mixed with toluene $(3 \%, v / v)$, shaken vigorously and stored at $-40^{\circ} \mathrm{C}$. Then, toluenized bacterial samples were thawed, and $2.7 \mathrm{ml}$ of a DAPI solution $\left(90 \mu \mathrm{g} \mathrm{l}^{-1}\right)$ was added to each sample. Measurements of DNA-DAPI complexes were made on a Jobin Yvon JY3D fluorometer. A blank was prepared with culture medium. Calf thymus DNA diluted in MM served as a standard.

Determination of protein synthesis. The bacteria were radioactively labelled with $\mathrm{L}-\left[{ }^{3} \mathrm{H}\right]$ alanine $\left(1.4 \mu \mathrm{Ci} \mathrm{ml}^{-1}\right)$ in the presence of L-alanine $(1 \mathrm{mM})$. Samples were removed at different times and proteins were precipitated with ice-cold $5 \%$ TCA. Samples were then filtered through Whatman GFB filters, rinsed with ice-cold TCA, dried, and the radioactivity determined in a scintillation counter.

Pulse-labelling of DNA. The bacterial cultures in $\mathrm{MM}^{+}$or $\mathrm{MM}^{-}$were pulse-labelled with $0.5 \mu \mathrm{Ci}\left[\right.$ methyl $-{ }^{14} \mathrm{C}$ ] thymidine $\mathrm{ml}^{-1}$ for approximately half the generation time. We have observed that $\left[\alpha-{ }^{32} \mathrm{P}\right] \mathrm{dTTP}$ also labels $H$. volcanii DNA so, in another experiment, we labelled cells for $1 \mathrm{~h}$ with $2 \mu \mathrm{Ci}\left[\alpha-{ }^{32} \mathrm{P}\right] \mathrm{dTTP}$ during exponential growth or amino acid starvation. Then, cells were collected by centrifugation at $6000 \mathrm{~g}$ for $15 \mathrm{~min}$, washed with $\mathrm{MM}^{-}$and lysed by resuspension in TE buffer [10 mM-Tris/HCl, $1 \mathrm{mm-EDTA} \mathrm{(pH} \mathrm{7 \cdot 5)].} \mathrm{The} \mathrm{samples} \mathrm{were} \mathrm{then}$ treated with RNAase A $\left(30 \mu \mathrm{g} \mathrm{ml}^{-1}\right)$ for $30 \mathrm{~min}$ at $37^{\circ} \mathrm{C}$, followed by proteinase $\mathrm{K}\left(100 \mu \mathrm{g} \mathrm{ml}^{-1}\right)$ treatment for $2 \mathrm{~h}$ at $37^{\circ} \mathrm{C}$ before phenol/ chloroform extraction and ethanol precipitation (Maniatis et al., 1982).

DNA was digested with $P s t \mathrm{I}$ or $\mathrm{XhoI}$ and subjected to $0.8 \%$ agarose gel electrophoresis. The gels were dried and autoradiographed.

Preparation of the pHV2 plasmid DNA probe. The plasmid $\mathrm{pHV} 2$ of $H$. volcanii (Charlebois et al., 1987) was isolated by $\mathrm{CsCl} /$ ethidium bromide buoyant density ultracentrifugation (Maniatis et al., 1982), digested with $P_{s t I}$ and subjected to $0.8 \%$ agarose gel electrophoresis. After electroelution from the gel, pHV2 DNA was labelled with $[\alpha-$ 
$\left.{ }^{32} \mathrm{P}\right] \mathrm{dATP}$ using the multiprime DNA labelling system as described by the supplier (Amersham).

Southern blot analysis. DNA was digested with various restriction enzymes according to the conditions suggested by the manufacturer (Boehringer). Agarose gel electrophoresis ( $0.8 \%$ ) and DNA blotting on Biodyne membrane (Pall) were performed as described by Kohiyama $e t$ al. (1986). Hybridization with [ $\left.{ }^{32} \mathrm{P}\right]$-labelled pHV2 DNA was carried out for $16 \mathrm{~h}$ at $42{ }^{\circ} \mathrm{C}$ in a buffer containing $50 \%(\mathrm{v} / \mathrm{v})$ formamide; $5 \times \mathrm{SSC} ; 1 \times$ Denhardt's solution (Maniatis et al., 1982); $20 \mathrm{mm-}$ sodium phosphate (pH 6.5); $250 \mu \mathrm{g}$ denatured E. coli DNA ml ${ }^{-1}$ and $10 \%(\mathrm{w} / \mathrm{v})$ dextran sulphate. Filters were washed first at room temperature in $2 \times \mathrm{SSC}, 0.2 \% \mathrm{SDS}$, then at $65^{\circ} \mathrm{C}$ in $0.1 \times \mathrm{SSC}, 0.1 \%$ SDS.

\section{Results}

Continuous DNA synthesis in minimal medium

The generation time in a his-1 mutant of Haloferax volcanii is $6-7 \mathrm{~h}$ when grown in minimal medium supplemented with histidine $\left(\mathrm{MM}^{+}\right)$, with continuous agitation at $37^{\circ} \mathrm{C}$. When histidine is not present in the minimal medium $\left(\mathrm{MM}^{-}\right)$, growth decreases rapidly and

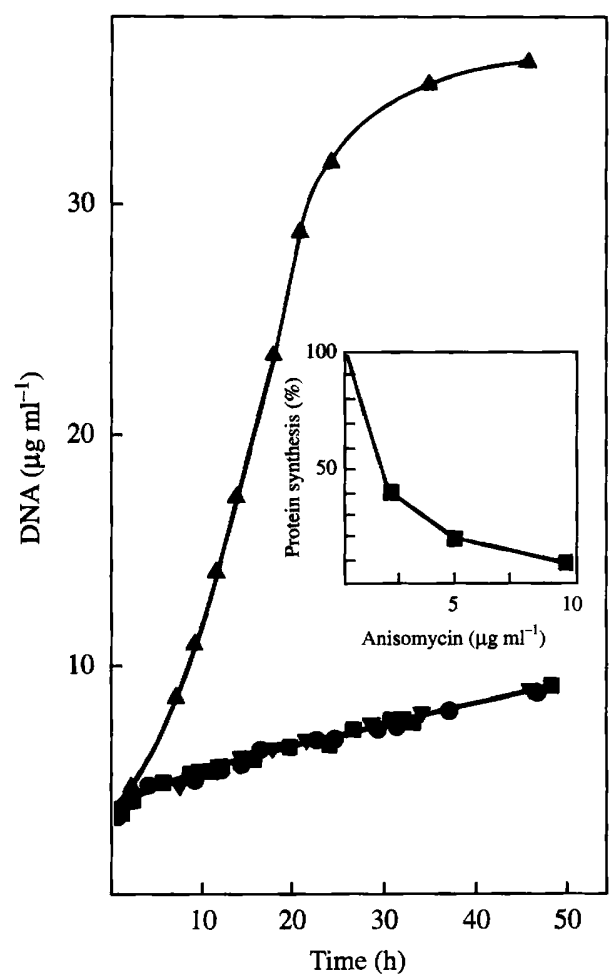

Fig. 2. Effect of anisomycin and histidine deficiency on DNA replication in a his-1 mutant of $H$, volcanii. The inset shows the effect of anisomycin on protein synthesis in $\mathrm{MM}^{+}$. Incorporation of $\mathrm{L}-$ $\left[{ }^{3} \mathrm{H}\right]$ alanine in anisomycin-treated cells is expressed as a percentage of that in control cells (without anisomycin) $5 \mathrm{~h}$ after the beginning of the treatment. The total DNA per $300 \mu \mathrm{l}$ of bacterial culture was measured at different times using DAPI determination. ( $\boldsymbol{\Delta}$ ) Exponential growth without anisomycin; $(\nabla)$ without amino acid starvation and with anisomycin $\left(10 \mu \mathrm{g} \mathrm{ml}^{-1}\right)$; (ם) amino acid starvation without anisomycin; (O) amino acid starvation with anisomycin $\left(10 \mu \mathrm{g} \mathrm{ml}^{-1}\right)$. ceases completely after about one doubling time. Amino acid starvation is sufficient to block protein synthesis with no significant effect on viability during the lag time in $\mathrm{MM}^{-}$(data not shown). After the addition of histidine, bacterial growth and protein synthesis resume (Fig. 1a). DNA synthesis was measured in $\mathrm{MM}^{+}$and $\mathrm{MM}^{-}$by fluorometry (see Methods). Fig. $1 b$ shows that the quantity of total DNA per cell increases continuously for at least $50 \mathrm{~h}$, despite the absence of concomitant protein synthesis. The rate of increase in DNA is comparable to about $15 \%$ of that observed during exponential growth in $\mathrm{MM}^{+}$, and the DNA content in $\mathrm{MM}^{-}$increases $2 \cdot 5$ fold in approximately $50 \mathrm{~h}$.

\section{DNA synthesis is not due to residual protein synthesis}

Anisomycin, a specific inhibitor of protein synthesis in eukaryotes, has also been found to inhibit synthesis in some archaeobacteria (Bonelo et al., 1984). The minimal inhibitory concentration (MIC) of anisomycin for $H$. volcanii was determined to be $10 \mu \mathrm{g} \mathrm{ml}^{-1}$ in minimal medium (data not shown). At this concentration, the rate of protein synthesis is reduced by $93 \%$, as shown in the inset of Fig. 2 by following the radioactive labelling of proteins. In order to eliminate the possibility that continuous DNA synthesis results from residual protein synthesis during amino acid starvation, the effect of inhibiting translation by anisomycin in the his- 1 mutant was examined. When the his-1 mutant was grown in $\mathrm{MM}^{+}$containing anisomycin $\left(10 \mu \mathrm{g} \mathrm{m}^{-1}\right)$, continuous DNA synthesis occurred comparable to that in the absence of histidine $\left(\mathrm{MM}^{-}\right)$. In addition, this increase in DNA concentration was also observed even in $\mathrm{MM}^{-}$ containing anisomycin (Fig. 2). These results show that the residual continuing DNA synthesis is independent of concomitant protein synthesis.

\section{Continuous DNA synthesis in complete medium (CM)}

To verify that the increase in DNA concentration during inhibition of translation is independent of the type of medium, DNA synthesis was studied in complete medium in the presence of $10 \mu \mathrm{g}$ anisomycin $\mathrm{ml}^{-1} . H$. volcanii has a generation time of $5 \mathrm{~h}$ when grown in complete medium without anisomycin $\left(\mathrm{CM}^{-}\right)$at $37^{\circ} \mathrm{C}$. When anisomycin $\left(10 \mu \mathrm{g} \mathrm{ml}^{-1}\right)$ is added to the medium, protein synthesis ceases quickly, as shown by measuring $\mathrm{L}-\left[{ }^{3} \mathrm{H}\right]$ alanine incorporation (Fig. $3 a$ ). As expected, this is immediately followed by a drastic decrease in the growth rate and cell division ceases completely in 12-15 h. Plating dilutions of culture samples on $\mathbf{M M}^{+}$agar plates confirmed the lack of difference in number of viable cells during the lag time in $\mathrm{MM}^{-}$. In parallel, DNA synthesis was measured by $\left[{ }^{3} \mathrm{H}\right]$ thymidine incorporation. After 

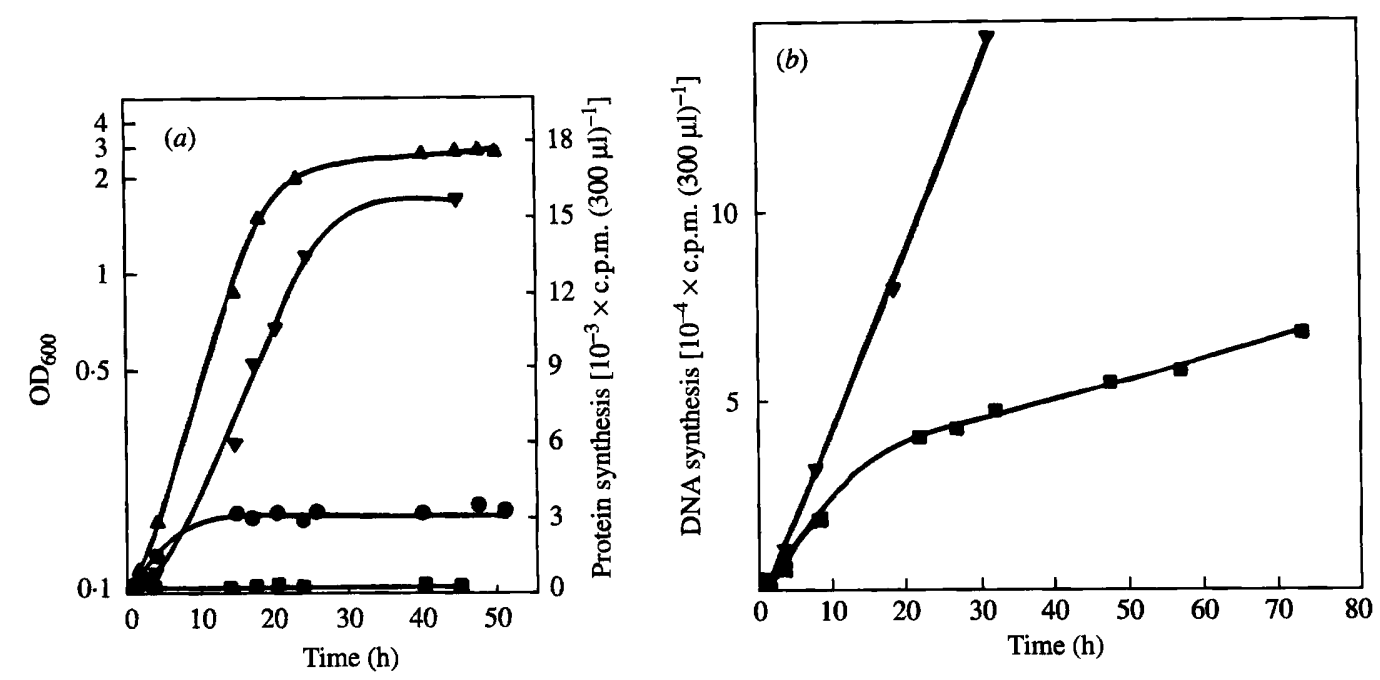

Fig. 3. Effect of anisomycin on bacterial growth, DNA synthesis and protein synthesis in the his- 1 mutant of $H$. volcanii. An exponential culture of the his-1 mutant in complete medium was divided into four portions. Anisomycin $\left(10 \mu \mathrm{g} \mathrm{ml}^{-1}\right)$ was added to two portions at $0 \mathrm{~h}(\boldsymbol{O}, \mathbf{\square})$. The cultures without anisomycin $(\Delta, \nabla)$ served as control. (a) For measurement of protein synthesis $1.4 \mu \mathrm{Ci} \mathrm{L}-$ $\left[{ }^{3} \mathrm{H}\right]$ alanine $\mathrm{ml}^{-1}$ was added to both types of culture at $0 \mathrm{~h}$ and incubation was continued for the indicated times at $37^{\circ} \mathrm{C}$. (A) Culture without anisomycin, $\mathrm{OD}_{600}(\log$ scale); $(\nabla)$ culture without anisomycin, radioactive labelling (linear scale); $(\bullet)$ culture with anisomycin, $\mathrm{OD}_{600}$ (log scale); ( $\mathbf{0}$ ) culture with anisomycin, radioactive labelling (linear scale). (b) For DNA synthesis measurement $1 \mu \mathrm{Ci}\left[{ }^{3} \mathrm{H}\right]$ thymidine $\mathrm{ml}^{-1}$ was added to both types of culture and DNA synthesis was measured by radioactive labelling of bacteria. ( $\nabla$ ) Culture without anisomycin; ( $\mathbb{\square}$ ) culture with anisomycin.

gradual slow increase of DNA synthesis, the linear incorporation of thymidine was found to continue for as long as $75 \mathrm{~h}$ in the presence of anisomycin (Fig. $3 b$ ).

\section{Continuous DNA synthesis is sensitive to aphidicolin}

We have previously shown that DNA replication in halophilic archaeobacteria is inhibited by aphidicolin (Forterre et al., 1984). DNA synthesis in the $H$. volcanii mutant was measured by $\left[{ }^{3} \mathrm{H}\right]$ thymidine labelling in the presence of various concentrations of aphidicolin. At $20 \mu \mathrm{g} \mathrm{ml}^{-1}$, DNA synthesis was inhibited by $95 \%$ (inset to Fig. 4).

We have looked for the effect of aphidicolin on the DNA synthesis observed in the absence of protein synthesis. As shown in Fig. $4,\left[{ }^{3} \mathrm{H}\right]$ thymidine incorporation into his-1 mutant DNA is inhibited by aphidicolin $\left(20 \mu \mathrm{g} \mathrm{ml}^{-1}\right)$ in both $\mathrm{MM}^{-}$and $\mathrm{MM}^{+}$bacterial cultures. This result shows that this continuous DNA synthesis, like normal DNA replication, is sensitive to aphidicolin. A similar result was obtained in rich medium in the presence of anisomycin (data not shown).

\section{Continuous DNA synthesis concerns chromosomal but not $p H V 2$ DNA}

The his-1 mutant was grown in $\mathrm{MM}^{-}$or $\mathrm{MM}^{+}$containing radioactive precursors of DNA synthesis $(2 \mu \mathrm{Ci}[\alpha-$ $\left.{ }^{32} \mathrm{P}\right] \mathrm{dTTP} \mathrm{ml}^{-1}$ or $0.5 \mu \mathrm{Ci}\left[{ }^{14} \mathrm{C}\right]$ thymidine $\left.\mathrm{ml}^{-1}\right)$. Total $\left[{ }^{32} \mathrm{P}\right]$-labelled DNA was then extracted and subjected to agarose gel electrophoresis. Autoradiography of the dried gel (Fig. 5a) showed that under normal conditions of bacterial growth both chromosomal and pHV2 $(6.4 \mathrm{~kb})$ plasmid DNAs were labelled (lane 2), whereas in amino acid-starved bacteria only the chromosomal DNA was labelled (lane 1). Thus, chromosomal DNA but not pHV2 plasmid DNA undergoes continued replication in the absence of protein synthesis. When these DNA samples were digested with the restriction endonucleases PstI (Fig. $5 b$ part A) or XhoI (Fig. $5 b$ part B), the pattern of labelled fragments from amino-acid-starved bacteria was generally similar to that of bacteria grown in the presence of histidine, except for some specific fragments $(6.4 \mathrm{~kb} \quad P s t \mathrm{I}-P s t \mathrm{I}, \quad 1.84 \mathrm{~kb} \quad X h o \mathrm{I}-X h o \mathrm{I}, \quad 1.25 \mathrm{~kb}$ XhoI-XhoI, $1.22 \mathrm{~kb}$ XhoI-XhoI, $0.99 \mathrm{~kb}$ XhoI-XhoI), which were preferentially labelled when the culture was not subjected to amino acid starvation (Fig. $5 b$, lanes 2). The sizes of these restriction fragments of pHV2 DNA corresponded to those observed for the pHV2 DNA digestion pattern (Charlebois et al., 1987). This suggests that the entire chromosomal DNA is replicated during continuous DNA synthesis. Thus, continuous synthesis involves the entire chromosomal DNA but not the pHV2 plasmid.

To confirm these results, total DNA from normal and anisomycin-treated bacteria was hybridized with a pHV2 $\left[{ }^{32} \mathrm{P}\right] \mathrm{DNA}$ probe (Fig. 6). In Fig. $6 c$, we show the densitometric analysis of the pHV2 plasmid band 


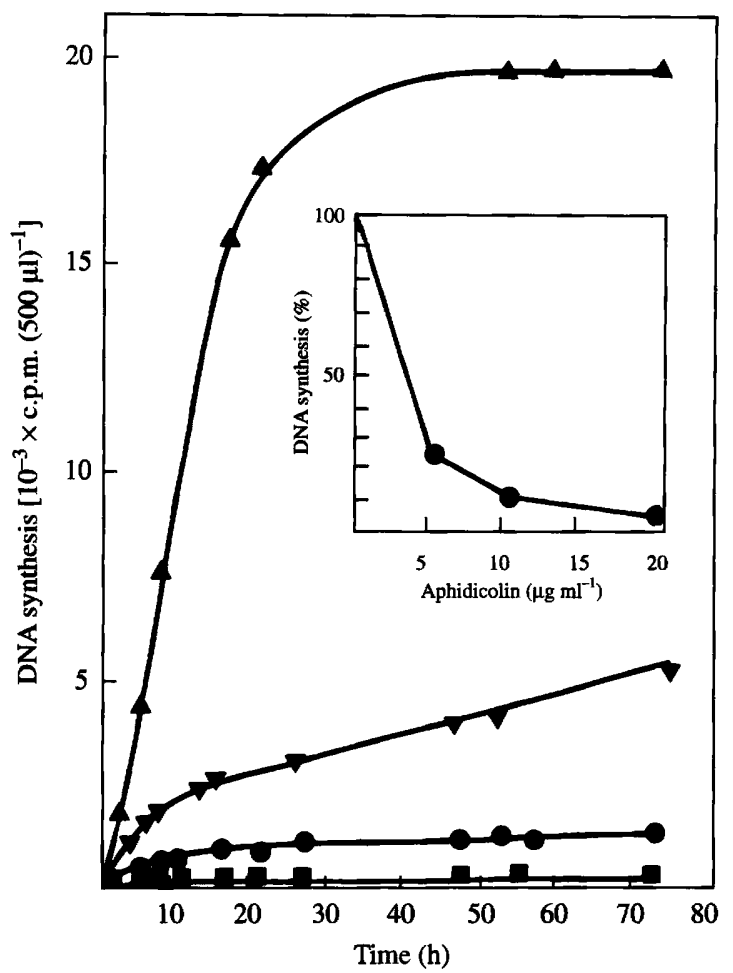

Fig. 4. Effect of aphidicolin and histidine deficiency on DNA replication in a his- 1 mutant of $H$. volcanii. The inset shows the effect of aphidicolin on DNA synthesis during exponential growth in minimal medium supplemented with histidine $\left(\mathrm{MM}^{+}\right)$. Incorporation of $\left[{ }^{3} \mathrm{H}\right]$ thymidine in aphidicolin-treated cells is expressed as a percentage of that in control cells (without aphidicolin) $15 \mathrm{~h}$ after the beginning of the treatment. An exponential culture of the his-1 mutant in $\mathrm{MM}^{+}$medium was washed with minimal medium without histidine $\left(\mathrm{MM}^{-}\right)$and divided into 2 portions. Histidine was added to one at $0 \mathrm{~h}$ and this culture served as a control. $\left.{ }^{3} \mathrm{H}\right]$ Thymidine $\left(1 \mu \mathrm{Ci} \mathrm{ml}^{-1}\right)$ was then added to both cultures at $0 \mathrm{~h}$ and DNA synthesis was measured by radioactive labelling of bacteria. Aphidicolin $\left(20 \mu \mathrm{g} \mathrm{ml}^{-1}\right)$ was also added at this time. (A) Without aphidicolin during exponential growth; ( $\boldsymbol{\nabla})$ without aphidicolin in amino-acid-starved bacteria; $(0)$ with aphidicolin and without amino acid starvation; ( $\boldsymbol{\square})$ with aphidicolin in amino-acidstarved bacteria.

intensities on Southern blots (Fig. $6 b$ ). It can be seen that the quantity of supercoiled pHV2 plasmid (arrow) is higher in total DNA from untreated than from anisomycin-treated bacteria. This is in agreement with the hypothesis that the pHV2 plasmid DNA does not replicate during the continuous DNA synthesis. The inhibition of pHV2 plasmid replication is reversible, since plasmid DNA synthesis resumes after the removal of anisomycin from the culture in complete medium or after the addition of histidine to bacterial cultures in $\mathrm{MM}^{-}$(data not shown). The upper band mostly corresponds to the position of chromosomal DNA. The fact that it is recognized by the pHV2 [ $\left.{ }^{32} \mathrm{P}\right] \mathrm{DNA}$ probe might be due to the presence of some high-molecularmass forms of the plasmid since we have not noticed any unspecific hybridization using the pHV2 [22]DNA probe.

\section{Discussion}

We have presented evidence that $H$. volcanii continues to replicate its DNA for up to $75 \mathrm{~h}$ during inhibition of protein synthesis with an apparent biphasic rate synthesis the first part of which is probably the run out of normal replication forks. As the quantity of DNA in $H$. volcanii increases 2.5-fold in about $50 \mathrm{~h}$ as shown using fluorometric DNA estimation (Fig. $1 b$, Fig. 2), reinitiation might occur in the absence of concomitant protein synthesis. We were unsuccessful in our attempt to use density labelling of bacteria, probably due to poor incorporation of 5-bromodeoxyuridine in $H$. volcanii (whose DNA is GC-rich). So, the possibility of reinitiation remains to be demonstrated since we have no information about the length of the $\mathrm{C}$ and $\mathrm{D}$ replication periods in the archaeobacteria kingdom.

Analysis of DNA replication patterns shows all the DNA of $H$. volcanii to be replicated in minimal medium without histidine with the exception of the pHV2 plasmid DNA. This is unlike some bacterial plasmids, such as the $E$. coli colicinogenic factor E1 (ColE1), where DNA replication is initiated during amino acid starvation (Bazaral \& Helinski, 1970).

The continuous DNA synthesis cannot be explained by residual run out or by repair-like synthesis since: (i) repair-like DNA synthesis does not normally result in an increase in the quantity of DNA. Thus, the increase in the DNA quantity shown with the DAPI method excludes this possibility. (ii) Increase (2.5-fold) of the quantity of DNA might suggest that reinitiation may occur during inhibition of protein synthesis. In the case of 'dichotomous' replication, as seen in E. coli, additional rounds of replication must, therefore, start on the same chromosome before previous rounds have terminated (McMacken et al., 1987). Hence, run out of replication forks might result in a bigger increase in the quantity of DNA. However, this kind of phenomenon usually happens when cells grow with a short doubling time or in minimal medium. (iii) This DNA synthesis is sensitive to aphidicolin, suggesting that it uses an aphidicolin-sensitive DNA polymerase as is the case with normal DNA replication. This kind of DNA polymerase has been purified from another halophilic archaeobacterium, Halobacterium halobium (Nakayama \& Kohiyama, 1985).

Under certain circumstances, $E$. coli exhibits altered modes of DNA replication. Induced stable DNA replication can occur in the absence of concomitant protein synthesis but only if DNA replication has been previously inhibited as during thymine starvation in a 


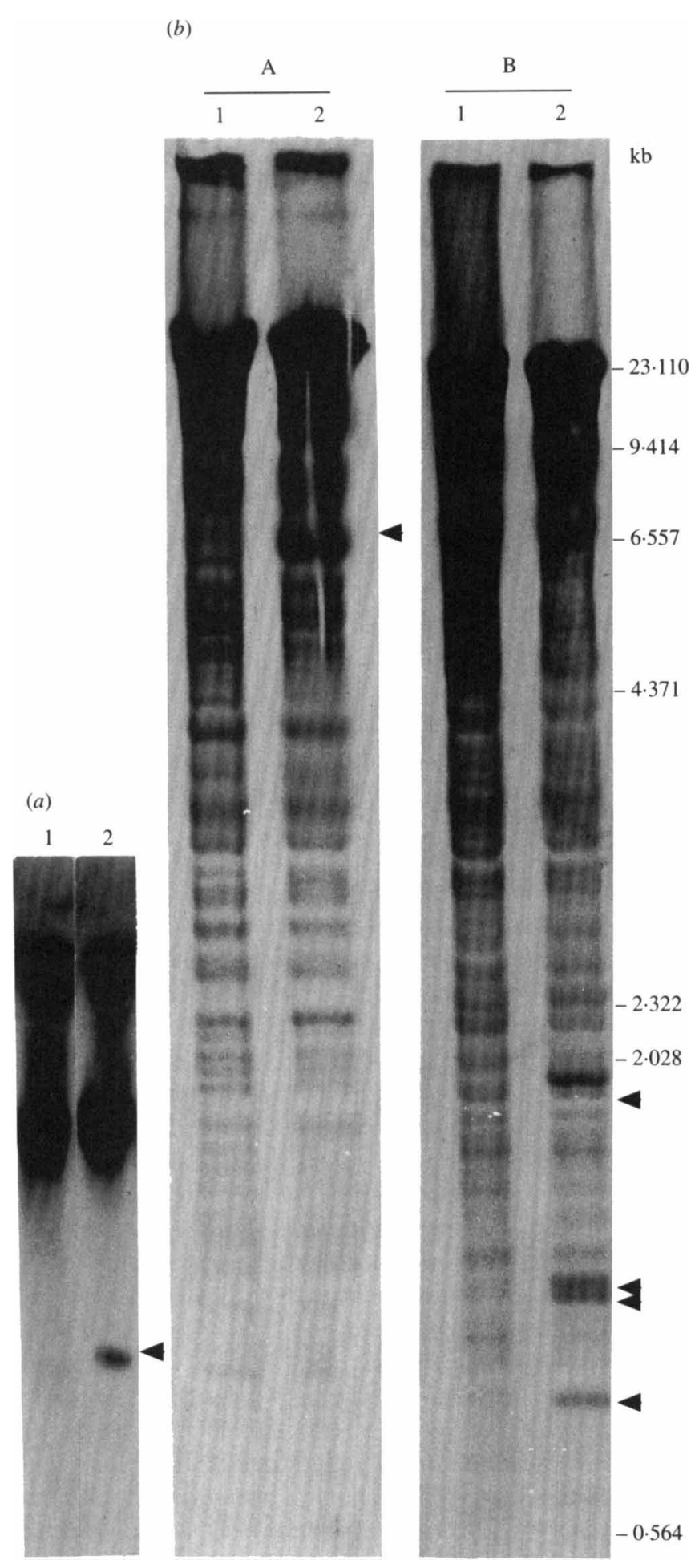

thymine-dependent mutant (Kogoma \& Lark, 1975; Magee \& Kogoma, 1990). Mutants constitutive for stable DNA replication, i.e. not requiring induction, have been isolated and found to be $r h h$ mutants, lacking RNAase H (Kogoma et al., 1985; Kogoma, 1986). In this respect, DNA synthesis in the absence of protein synthesis in $H$. volcanii resembles the latter. There are, however, some important differences. First, we do not know at this point whether the observed residual DNA replication is a normal fraction of total DNA synthesis in $H$. volcanii or whether it is induced by the treatments which stop protein synthesis. Second, the total quantity of DNA synthesized after $60 \mathrm{~h}$ in $H$. volcanii is considerably less than that observed in a $r n h$ mutant of E. coli (Kogoma, 1986).

Further experiments will be necessary to determine whether this particular type of DNA synthesis is part of the normal replication in $H$. volcanii and what importance it can play in replication. On the other hand, our data might indicate that during the inhibition of protein synthesis, a change occurs in the cell which results in the ability to initiate cycles of replication in the absence of further protein synthesis. This potential should be stable and might involve a mechanism which is re-used in several cycles of DNA replication, as in RNAase H-defective mutants of $E$. coli. The proteins involved would be part of the normal replication apparatus, since aphidicolin, which affects normal DNA replication, also affects the continuous DNA replication observed after the inhibition of protein synthesis.

The production of supercoiled $\mathrm{pHV} 2$ plasmid is stopped during the inhibition of protein synthesis by anisomycin or by amino acid starvation. The DNA replication pattern of amino-acid-starved bacteria shows that the pHV2 plasmid is not labelled and that its replication is stopped (Fig. 5). The initiation of pHV2 replication might require labile factors which must be synthesized in each cell cycle as described for most $E$. coli plasmids.

The inhibition of supercoiled pHV2 monomer DNA production is confirmed by hybridization experiments, but the upper signal in Fig. 6 reveals the existence of some kind of high-molecular-mass plasmid multimers.

Some of our preliminary results (data not shown) suggest that the upper signal in Fig. 6 might be due to

Fig. 5. DNA replication pattern during amino acid starvation of the his-l mutant. An exponential culture of $H$. volcanii in minimal medium supplemented with histidine $\left(\mathrm{MM}^{+}\right)$was washed with the same medium without histidine ( $\mathrm{MM}^{-}$) and divided into two portions. Histidine was added to one, which served as control. Two radioactive pulses were done, one in the exponential culture in $\mathrm{MM}^{+}$ medium (lanes 2) and the second in the amino-acid-starved bacteria in $\mathrm{MM}^{-}$medium (lanes 1). Samples were taken and the total DNA was extracted, digested or not, the same quantity of radioactivity was electrophoresed and autoradiographed. The arrowhead indicates the position of pHV2 plasmid DNA. (a) [ $\left.\alpha^{32} \mathrm{P}\right] \mathrm{dTTP}$ pulses of $1 \mathrm{~h}$ after $45 \mathrm{~h}$ of amino acid starvation in the culture without anisomycin, and during exponential growth for the culture with histidine. The total DNA was applied to an agarose gel without prior digestion. (b) $\left[{ }^{14} \mathrm{C}\right]$ Thymidine pulses for $0.5 \times$ doubling time in the exponentially-growing culture and for $19 \mathrm{~h}$ in the amino-acid-starved culture. (A) PstI digestion of the DNA samples. (B) XhoI digestion. The molecular mass markers are indicated on the right. 
(a)

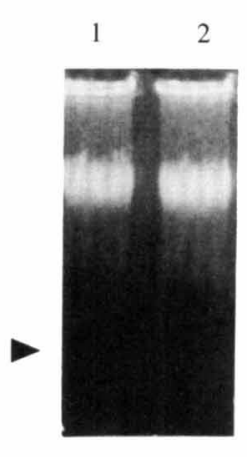

(c)
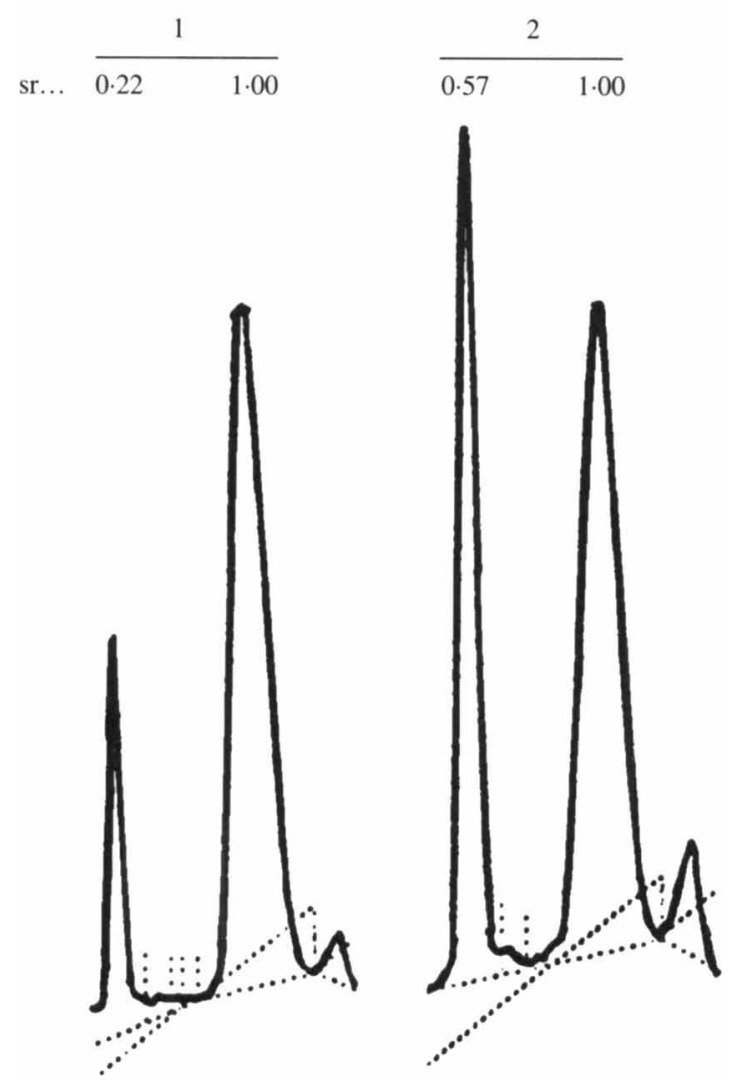

Fig. 6. pHV2 plasmid DNA does not replicate during inhibition of protein synthesis in complete medium. An exponential culture of the his-1 mutant in $\mathrm{CM}$ without anisomycin $\left(\mathrm{CM}^{-}\right)$was split into two portions. To one $\left(\mathrm{CM}^{+}\right) 10 \mu \mathrm{g}$ anisomycin $\mathrm{ml}^{-1}$ were added (lanes 1). The portion without anisomycin served as control (lanes 2). A sample of the anisomycin-treated culture was taken after $45 \mathrm{~h}$. Equal amounts of total cell DNA were subjected to $0.8 \%$ agarose gel electrophoresis in the presence of ethidium bromide $(a)$. The gel was transferred onto a Biodyne membrane and hybridized with a $\left.{ }^{32} \mathrm{P}\right] \mathrm{pHV} 2$ probe $(b) .(c)$ Densitometric scannings of $(b)$. The arrowhead indicates the position of the supercoiled pHV2 monomer DNA. sr: Surface ratio.

some concatemeric forms of plasmid or to unresolved pHV2 plasmid replication intermediates which might be resolved only in the presence of protein synthesis, thus allowing production of supercoiled pHV2 monomer DNA.

Further experiments are necessary to elucidate the mechanism of $\mathrm{pHV} 2$ plasmid replication and the effect of protein synthesis on this mechanism.

We are grateful to P. Hughes and D. D'Ari for helping with the English version and for helpful discussion and to A. Bracone for technical assistance. I.S. was supported by Ligue Nationale Contre le Cancer.

\section{References}

Bazaral, M. \& HelinsKi, D. R. (1970). Replication of a bacterial plasmid and an episome in Escherichia coli. Biochemistry 9, 399-406.

Ben Mahrez, K., Sorokine, I., Nakayama, M. \& Kohiyama, M. (1991). Reverse transcriptase in archaebacteria. Purification and characterization of a primase-reverse-transcriptase complex from Halobacterium halobium. European Journal of Biochemistry 195, 157-162.

Bonelo, G., Ventosa, A., Megias, M. \& Ruiz-Berraguero, F. (1984). The sensitivity of halobacteria to antibiotics. FEMS Microbiology Letters 20, 341-345.

Charlebois, R. L., Lam, W. L., Cline, S. W. \& Doolittle, W. F. (1987). Characterization of pHV2 from Halobacterium volcanii and its use in demonstrating transformation of an archaebacterium. Proceedings of the National Academy of Sciences of the United States of America 84, 8530-8534.

Elie, C., DE Recondo, A. M. \& Forterre, P. (1989). Thermostable DNA polymerase from the archaebacterium Sulfolobus acidocaldarius. Purification, characterization and immunological properties. European Journal of Biochemistry 178, 619-626.

ForTerRe, P., Elie, C. \& Kohryama, M. (1984). Aphidicolin inhibits growth and DNA synthesis in halophilic archaebacteria. Journal of Bacteriology 159, 800-802.

Hamal, A., Forterre, P. \& Elie, C. (1990). Purification and characterization of a DNA polymerase from the archaebacterium Thermoplasma acidophilum. European Journal of Biochemistry 190, 517-521.

KuimczaK, L. J., Grummt, F. \& Burger, K. J. (1985a). Purification and characterization of DNA polymerase from the archaebacterium Sulfolobus acidocaldarius. Nucleic Acids Research 13, 5269-5282.

KLIMCZAK, L. J., GrUmmt, F. \& BURGER, K. J. (1986b). Purification and characterization of DNA polymerase from the archaebacterium Methanobacterium thermoautotrophicum. Biochemistry 25, $4850-4855$.

KoGOMA, T. (1986). RNase H defective mutants of Escherichia coli. Journal of Bacteriology 166, 361-363.

Kogoma, T. \& LARK, K. G. (1975). Characterization of the replication of Escherichia coli DNA in the absence of protein synthesis: stable DNA synthesis. Journal of Molecular Biology 94, 243-256.

Kogoma, T., Skarstad, K., Boye, E., von Meyenburg, K. \& Steen, H. B. (1985). RecA protein acts at the initiation of stable DNA replication in $r n h$ mutants of Escherichia coli K-12. Journal of Bacteriology 163, 439-444.

Kohyama, M., Nakayama, M. \& Ben-Mahrez, K. (1986). DNA polymerase and primase-reverse transcriptase from Halobacterium halobium. Systematic and Applied Microbiology 7, 79-82.

LARK, K. G., REPCo, T. \& Hoffman, E. J. (1963). The effect of amino acid deprivation on subsequent DNA replication. Biochimica et Biophysica Acta 76, 9-24.

LEGROS, M. \& KEPES, A. (1985). One-step fluorometric microassay of DNA in procaryotes. Analytical Biochemistry 147, 497-502.

MaAloe, O. \& Hanawalt, P. C. (1961). Thymine deficiency and the normal DNA replication cycle. Journal of Biological Chemistry 3, $144-145$.

McMacken, R., Silver, L. \& Georgopoulos, C. (1987). DNA replication. In Escherichia coli and Salmonella typhimurium: Cellular 
and Molecular Biology, pp. 564-612. Edited by J. L. Ingraham, K. B. Low, B. Magasanik, F. C. Neidhardt, M. Schaechter \& H. E. Umbarger. Washington, DC: American Society for Microbiology.

MaGEe, T. R. \& Kogoma, T. (1990). Requirement of RecBC enzyme and an elevated level of activated RecA for induced stable DNA replication in Escherichia coli. Journal of Bacteriology 172, 1834-1839.

Maniatis, T., Fritsch, E. F. \& SAMbrook, J. (1982). Molecular Cloning: a Laboratory Manual. Cold Spring Harbor, NY: Cold Spring Harbor Laboratory.

MEVARECH, M. \& WERCZBERGER, R. (1985). Genetic transfer in Halobacterium volcanii. Journal of Bacteriology 162, 461-462.

von MEYendurg, K. \& HANSEN, F. G. (1987). Regulation of chromosome replication. In Escherichia coli and Salmonella typhimurium: Cellular and Molecular Biology, pp. 1555-1577. Edited by J. L. Ingraham, K. B. Low, B. Magasanik, F. C. Neidhardt, M. Schaechter \& H. E. Umbarger. Washington, DC: American Society for Microbiology.

Nakayama, M. \& Kohiyama, M. (1985). An alpha-like DNA polymerase from $H$. halobium. European Journal of Biochemistry 152, 293-297.

Nakayama, M., Ben-Mahrez, K. \& Kohtyama, M. (1988). DNA primase activity found in an alpha-like DNA polymerase obtained from Halobacterium halobium. European Journal of Biochemistry 175, 265-270.

Salhi, S., Elie, C., Jean Jean, O., Meunier Rotival, M., Forterre, P., Rossignol, J. M. \& De Recondo, A. M. (1990). The DNA polymerase from the archaebacterium Sulfolobus acidocaldarius a thermophilic and thermoresistant enzyme which can perform automated polymerase chain reaction. Biochemical and Biophysical Research Communications 167, 1341-1347.

SOROKINE, I. \& KoHIYAma, M. (1988). Synthèse résiduelle et continue d'ADN chez un mutant auxotrophe [His] de l'archaebactérie halophile Halobacterium volcanii carencé en un acide aminé. Compte Rendu de l'Académie des Sciences Série III, Paris 306, 85-88.

Torreblanca, M., Rodriguez-Valera, F., Juez, G., Ventosa, A., KAMEKURA, M. \& KATES, M. (1986). Classification of non alkaliphilic halobacteria based on numerical taxonomy and polar lipid composition, and description of Haloarcula gen. nov. and Haloferax gen. nov. Systematic and Applied Microbiology 8, 89-99.

WOESE, C. R. \& OlsEN, G. J. (1986). Archaebacterial phylogeny: perspectives on the urkingdoms. Systematic and Applied Microbiology 7, 161-171.

ZABel, H. P., FisCher, H., Holler, E. \& WinTER, J. (1985). In vivo and in vitro evidence for eucaryotic $\alpha$-type DNA polymerase in methanogens. Purification of the DNA polymerase of Methanococcus vannielii. Systematic and Applied Microbiology 6, 111-118. 